\title{
MIRV, MARV AND FOBS: \\ Language and Significances in a Selection of Post- nuclear Texts for Young Adults
}

\author{
Elizabeth Braithwaite
}

I $\mathrm{n}$ his book Nuclear Criticism, Ken Ruthven describes how the language used in the nuclear debate frequently L'corrupt[s] communication into disinformation' (p.56). Euphemisms such as 'nuclear exchange' rather than 'nuclear war' (p.54), appropriation of signifiers such as 'Armageddon' (p.19) and use of acronyms such as those in the title of this paper' all serve to create a gap between nuclear weaponry itself and the way in which readers are encouraged to perceive it. For example, euphemisms can manipulate readers into an ideological position by suggesting that the nuclear issue is not as dangerous as might be suspected. Similarly, the use of labels such as 'Trinity' (Ruthven 1993, p.1) and 'Armageddon' suggest that the nuclear debate has religious implications, which may turn the reader's mind away from the possibility that she may be capable of agency. And. as Ruthven says, the use of acronyms such as FOBS takes the audience two degrees away from the reality of what the writer/speaker claims to be representing. How many lay people, for example, would be able to explain the concept of a 'fractional orbital bombardment system' even if its name were given in full? By abstracting the title of the weapon into an acronym, the speaker/writer can position the audience to be "becoming completely anaesthetised to the effects of the weapons themselves' (p.56). Thus, language in the nuclear debate frequently encodes power relations whereby those who massage the conventional meanings of language attempt to influence others, often by promoting an ideological position which can be difficult for the reader to oppose. There can also be a gap between what is said and what is meant: Christa Wolf, for example. entitled her 1987 text on Chernobyl 'Incident', and the deliberately ironic title highlights this gulf (Ruthven 1993, p. 55).

Many young adult post-nuclear texts utilise language in a similar manner to the techniques listed above. 'Postnuclear fiction' may be defined as a category of fictional texts which deal with life after a nuclear accident or a nuclear war. ${ }^{2}$ Such texts may or may not include an actual bombing or release of nuclear power, but their chief focus is usually the survival and personal development of at least one of the protagonists, and the action of the text is often presented from the point of view of this person. This paper will focus on Robert O'Brien's Z for Zachariah
(1975), Hugh Scott's Why Weeps the Brogan? (1989), Raymond Briggs's When the Wind Blows (1982), Robert Swindells' Brother in the Land (1984) and Isobelle Carmody's Obernewtyn chronicles (1987-1999), but many of the trends in these texts are aiso present in other works within the genre.

$Z$ for Zachariah is an carly text in the post nuclear genre, and passages of dialogue between the two main characters, Mr Loomis and Ann, demonstrate the shift in power between them. For example, in the final scene, it is Ann's words which save her life (p.186) and she speaks calmly and with authority whilst $\mathrm{Mr}$ Loomis babbles anxiously (p.187). The last image of Mr Loomis represents him calling anxiously to Ann while she strides silently away in the safesuit, before she finally stops to listen to him and acknowledge (nonverbally) what he has said. This final scene suggests a significant change in the power relations between the two characters. In previous scenes, $\mathrm{Mr}$ Loomis has tried to manipulate Ann through language: when she explains her plan for living in a different part of the valley and bringing food and water as Mr Loomis requires them, $\mathrm{Mr}$ Loomis responds by saying, 'I can only hope you will...act more like an adult and less like a school girl' (p.144). While the use of language in this manner may be true of any relationship in which a young person is exploited or manipulated by a more powerful adult, Mr Loomis's other use of rhetoric and technical vocabulary is similar to the way in which jargon is used in the nuclear debate to cloud an unpalatable reality.

In Why Weeps the Brogan?, Panguage is presented as a means by which the central characters attempt to exercise power over the world in which they find themselves. There is a suggestion that rediscovering their surname is a key issue in the children's attempts at solving their problems ( $\mathrm{p} .9$ ); their surname has become symbolic both of their past and their identity. Indeed. their search for their family name becomes a type of quest both for selfhood and a place in the world; for example, when Gilbert asks 'What is our other name?' it precipitates a discussion on mernory, age and worlds other than the children's immediate surroundings(1991, p.9). Similarly, at the climax of the novel, Saxon knows not only that their surname is Brogan but also what has brought her and her
Copyright of Full Text rests with the original copyright owner and, except as permitted under the Copyright Act 1968, copying this copyright material is prohibited without the permission of the owner or its exclusive licensee or agent or by way of a licence from Copyright Agency Limited. For information about such licences contact Copyright Agency Limited on (02) $93947600(\mathrm{ph})$ or (02) 93947601 (fax) 
brother to their present predicament (pp. $102-3$ ). A direct relationship is implied between Saxon's discovery and the manner in which the closing words of the text are presented as calm statements of fact: 'We have been here four years, eighty-five days....I am Saxon. This is my brother Gilbert. Saxon and Gilbert and Saxon Brogan. Our mother is dead' (p. 103). This passage contrasts with the representation of communication which precedes it, in which words such as 'screams, ... whispered ... blood flowed cold.... whimpered .... gaped' (pp.102 -103) suggest a frenzy of fear and uncertainty. Saxon's speech suggests that she, at least. experiences some sense of identity, and hence has a degree of control at least within herself. It is implied, therefore, that for the children to know their surname is for them also 'to know the meaning immanent in [their] selfhood" (Stephens 1992a, p 267). This is particularly true for Saxon as focaliser. Whilst names in general may be seen as a particular way of validating identity, there is a sense that for Saxon and Gilbert names are also a means of maintaining sanity. This is demonstrated by Saxon's use of Gilbert's name to maintain control in a situation in which she feels she has little power. At least the relationship between the signifier 'Gilbert' and the person who answers to that name seems-to Saxon-to be relatively stable.

In the opening scene, Saxon is described as using Gilbert's name 'carefully lest she forget' (p.7). At this stage the reader knows little of the relationship between Saxon and Gilbert. except to infer that, by her 'gentie' command to Gilbert to 'eat [his] rolls while they're hot' (p.7), Saxon is possibly dominant. It may seem odd to the reader, therefore, that Saxon is in danger of forgetting Gilbert's name, but it heightens the dislocation that is created in this first scene. Images such as 'speeding on plunging limbs [and] a girl's head fell from the balcony' - to which Gilbert's only response is a sigh (p.7)-invite the reader to infer that in the world constructed in the text it is not wise to make too many assumptions. As John Stephens writes, 'figurative effects are produced by dislocations of [consensus] surface meaning. violations of the audience's sense of empirical reality' (Stephens 1992a, p.246). The phrase 'lest she forget' also has resonances with the injunction frequently given to survivors of and those who came after the two World Wars, so relating the characters' experience to broader discourses of war. This association underscores the horror of the children's situation when the reader realises that it is probably a nuclear war through which the children have passed (p.15) and that there may well be no one else to forget-or to remember.

The children's ritualistic and artificial way of speaking, especially in the first part of the novel, is also represented as a mode of control over a situation which is out of control. For example, interchanges such as 'You may spread me a second roll' followed by 'You may pour me a third coffee' are the means by which the children restore their emotional equilibrium ( $p .9$ and p.30, for example). Similarly, Saxon helps Gilbert to calm his emotions by encouraging him to recite a list of names from the 'ORNITHOLOGY' section of the museum (p.30). It is significant that it is names of birds which Gilbert and Saxon recite, since these names link them to the Brogan who 'feed [s] beneath the dribbling blue bird' ( $p .7$ ) and to the positive significances of sparrows within the text. Saxon says to Gilbert. 'There is so much ...still to learn'; her attempt to make meaning out of meaninglessness is thereby encoded in the order and logic of lists. When she finally achieves understanding. her calm explanation of her situation is a long way from the machine-like reciting of lists but carries through the idea that listing has a calming effect.

Just as reciting the ORNITHOLOGY list gives Saxon and Gilbert some illusion that they have control in their situation, language in When the Wind Blows is a means by which 'the government' seeks to assure the people of Britain that it has some powe: in the nuclear situation. Missives from the government $2 \mathrm{se}$ what has been described as 'nukespeak' (Ruthven 1993 . . . .55), inspired by George Orwell's 'Newspeak', in 1984. Whether through jargon, acronyms, euphemisms or slogans. nukespeak helps to "take us even further away trom the reality of nuclear weaponry" (Ruthven 1993, 7.55). In When the Wind Blows, Raymond Briggs higiights the pathos of this practice, and how it can 3 perdinary peopie into believing that someone is in sestrol. For example, Jim has borrowed a book from to Public Library entitled Armageddon and $Y o u$ and gisestly exhorts his wife to listen to the 'triffic bit in it avor Western Defences': 
There-are-three-BMEWS-(Ballistic-MissileEarly-Warning-Systems-)One-PARCS (Perimeter-Acquisition-Radar-AttackCharacterisation-System) then-there 's-NORAD(North American-Air Defence)-and JSS-(JointSurveillance-System) and-then-seven-(RegionalOperation-Control-Centres-), and then there's NADGE (NATO-Air-Defence-GroundEnvironment)-and several AWACS (Air-borneWarning-and-Control-Systems).

(p.25)

The list goes on. The dashes which link the words sugges that the list forms a litany which is simply to be repeated, with no deeper significance. Jim is clearly 'BMEWSed' by the avalanche of acronyms and jargon, for even when his wife observes that it has not keep them safe from being bombed. Jim pulls the last tragic rabbit from the hat: - $[A]$ nother thing that the Powers That Be have created is called M.A.D[:]...Mutual Assured Destruction.' That neither Jim nor Hilda comprehends the implications of this acronym is demonstrated by the way in which the conversation immediately turns to Hilda's reminiscences of her father's life in an Insurance company, his beautiful funeral, and the pride Jim has in having his own funeral 'fully assured' (p.25). Indeed, one of the central issues in Briggs's When the Wind Blows is the danger of listening too closely to the rhetoric of the government. Briggs uses the grandiose but empty language of officialdom to show how powerless an individual person is in the event of a nuclear disaster. Readers are thereby positioned to interrogate the utterances of organised authority and especially government bodies.

However. friendly, ordinary, retired James, who lives an 'uneventful' life in which he reads the newspapers in the Public Library, kisses his wife, and says a friendly 'Cheerio' to the bus driver (p.l), has been thoroughly taken in. Self-important phrases such as 'International Situation' and 'The Powers That Be' (p.l) litter Jim's conversation; similarly, in the humour and horror of Hilda's misunderstanding of the difference between 'Fall Out' and 'fall in' and her disapproval at Jim's expression 'Blimey', Briggs has positioned readers to extrapolate beyond how Hilda and Jim understand language. Just as
Scott's paraphrase of 'lest we forget' reminds readers of the differences between the previous World Wars and a potential nuclear one, so too does Hilda's reference to the Army underscore differences between conventional warfare and the nuclear (p.2). Thus, Jim's attempt to use the language of the previous World Wars highlights the hopelessness of their situation, since phrases such as 'All-Clear' and 'Put that light out' as well as clichés such as 'pulling our weight....putting our shoulders to the wheel...all pull together, now that our backs are against the wall' (pp.23 and 25) are meaningless in the face of nuclear war. Throughout the text, Briggs implies that individuals must work towards disarmament, because all government bodies can offer is clever linguistic constructions offering highly unstable relationships between sign, signifier and referent.

Although Carmody's Obernewtyn chronicles are very different from Briggs's text, the use of language as a means of constructing power is similar. For example, the introduction to Obernewtyn implies that the rigid naming of acts and characteristics is a form both of exercising control and of creating the illusion there is someone in control. The terms 'Herder Faction, Misfit. Seditioner, Guardian, Assistant' give the impression of a tightly ordered society, and the capitalisation of the word 'Burning' implies a significance which reduces horror; 'Witnessing a Burning' reads like a ritual act. not the brutal torture of another human being. The gap between signifier and signified, and between sign and referent, is particularly evident in this instance. The Misfits, also, have their own labels, such as 'guildmerge', 'farseeker' and 'deepprobing' (1987, pp.248,284, 115); and the beasts have their own signifiers such as 'funaga' for humans and 'leashname' for the name given to an animal by humans (1999, pp.5, 13). Just as the Council has appropriated words such as 'misfit', 'sedition' and 'burning' and recoded them as specific labels, so too does the Misfit community appropriate words such as 'Choose', 'coercer', and 'sent' (1993, pp.315.316; 1995, p.337), as well as attaching a new meaning to 'Talent', the meaning 'telepathy' (1999, p.428). In these instances the relationship between signifier and signified is constructed as very precise. and by this means Carmody promotes reader alignment with Elspeth and her friends by providing 
readers with inside knowledge concerning the recoding of words such as 'Talent', 'Chocse' and 'coercer', as well as invented words such as 'guildmerge' and 'funaga'.

Names are given a particular significance in the Obernewtyn series, both as a means of hiding identity and also as a means of validating it. For example, Elspeth uses the name 'Elaria' as a means of concealment, and she wonders whether the gypsy is 'less important than whatever this name [Swallow] meant' (1995, p.256). Once again, the unstable relationship between signifier and signified is highlighted: whereas Saxon appears to believe that Gilbert's name (and their own surname) is intricately connected with selfhood, Carmody implies quite the opposite by way of focalisation through Elspeth. On the other hand, the white dog who has freed the other animals from the repressive farm on which they live is emancipated by being named Rasial (1999, p.13). It is important that the name has been offered (as opposed to imposed) by the mare Avra, for she (Avra) has just been described as having 'the ability to harmonise with all things' (p.13), a central value of the Obernewtyn series. Accepting the name, therefore, is symbolic of Rasial's freedom from her repressive past.

Names are also significant for the humans in the Obernewtyn texts. The name 'Innle' is frequently applied to Elspeth, and one of the questions posed in the text is whether she is the saviour from the legends of the beast world (1999, p. 14). People are also exhorted not to call the evil Ariel by name, since that may, it is suggested, bring down immediate wrath (1993, p.306). Ariel's very name is ironic, for at the end of The Keeping Place Elspeth realises that Arie! is the Destroyer (1999, p.753). and yet Ariel is also a name meaning 'lion of God' (Isaiah 29:1). This dislocation encourages readers to adopt the humanist view of the world presented by the texts: humanity has responsibility for itself and cannot blame God, who seems to exist largely to punish (1995, p. ix). Far from relying on God, Carmody suggests that the path of hope depends on relationships between humanity and the world; as Maruman the cat tells Elspeth. 'You do not live only for yourself' (1999, p.746).

Language constructs power in a rather different way in Brother in the Land, where it relates to one of the other characteristics of language use in post-nuclear texts, namely the attempt to construct an ideological position capable of disempowering readers. The implied readers of this text are well-versed in the literary canon and also fimly entrenched in the middle class. The narrator, for example, is highly articulate, with a sound knowledge of canonical and classic Western literature: 'I fancied they'd be keeping accurate time up at Kershaw Farm, and maybe there was somebody somewhere cutting notches in a pole like Robinson Crusce' (p.54). The deliberate misquotation '[A]ll ruads lead to Rhodes' (p. 147) also presupposes that the reader has literary knowledge, as does the quotation 'Water, water everywhere, nor any drop to drink' (p.12), which suggests that Danny is familiar enough with the literary canon to adapt the text. His reference to 'that poem about the Ancient Mariner' (p.12, my emphasis) assumes that the reader at least knows of Coleridge's poem. Even Danny's occasional lapses into slang, such as: 'Aye ... I just hope they do summat for us when they do' and 'Shaddap' (pp.24, 58), do little to counteract the overwhelmingly well-educated, middle class tone of the novel. Danny's attempt to speak in the words of an implied lower class merely emphasises that he is not part of it.

Stephens notes that if the only variations from standard English occur in conversation and not in narration, then the most obvious subject position for a reader is to be within the culture of people who speak standard English (Stephens, 1992a, p.53). Danny's slang, furthermore, quickly disappears, and there is a strong link between morality and dialect, in that characters who speak nonstandard forms of English are some of the most evil; for instance, Charlie and Ken, who attack the 'badgers' (pp.46, 47). This is an example of a practice which Hollindale regards as ideologically suspect: the collation of virtues in order to 'articulate [a] ... larger virtue' (p.20). In Brother in the Land, conversely, speaking consistently in non-standard English is associated with selfishness and evil. To an extent, speaking in standard Enghish is also linked with moral virtue in this first part of the novel, but it is an unselfconscious way of speaking articulately which is valued, not the strained, artificial voice of the evil authorities at Kershaw Farm: legalistic phrases such as 'fleet of ambulances', 'able-bodied' and 'persons 
suffering from minor injuries' (p.36, my emphasis) seem over-formal and appear to represent an attempt to objectify and depersonalise events. However, even at this stage of the novel the reader has been positioned in such a way so as to be alerted to the very real difference between what 'the authorities' are promising and what they actualty deliver (pp.32, 41).

Just as Briggs positions his readers to distrust governments and official bodies, so too, does Swindells imply that formal authorities are not to be trusted. A similar technique is used in Z for Zachariah, in which Ann's collation of virtues is linked with her style of speaking. Whilst pointing out the complexities of the two characters, Suzanne Keene suggests that Loomis represents a world of high intellect but low emotional growth, of a desire to control, and a world in which technology destroys the environment. As Keene also notes, Ann, on the other hand, can put her own need to survive aside whilst she cares for others, is able 'to feel pity and compassion' and sees technology as a means of nurturing the earth as well as taking from it (p.7). Ann's unsophisticated mode of address, when combined with the construction of her virtue and courage (as opposed to Mr Loomis' cruelty and selfishness) suggest that the reader is being encouraged to believe that 'natural and simple' is best. For example. Mr Loomis talks of a 'Geiger counter ... radiation sickness... intracellular ionization' whereas Ann talks of 'those glass tubes you have...[and] how bad will it get?' (pp.40-4I).

The use of labels with cultural significances is another means by which an audience can be positioned. For example, mythic significance is given to the nuclear disaster in Isobelle Carmody's Obernewtyn and its sequels by the use of particular signifiers: the nuclear disaster is referred to as 'the Great White' $(1987$, p.1). Again, the book from Jim's Public Library refers to a nuclear attack as 'Armageddon', as do the inhabitants of the Dome in Dobson's The Inheritors (p.2). 'Armageddon' has generally been one of the most popular labels for a prospective nuclear war (Ruthven 1993, p.18); it is instructive to note the similarities between the biblical account of Armageddon and the description of nuclear warfare given in Swindells' text. In the Book of
Revelation. Armageddon is a place to which all the kings of the world are called, whereupon an angel empties the seventh bowl of God's anger upon the earth, a voice shouts 'The end has come', there are 'flashes of lightning and peals of thunder', a violent earthquake, and all the cities of the world collapse (Revelation 16:1, 14, 16, 18, 19). Swindells' account of the nuclear attack is as follows:

Whole towns and city centres [are] vaporized instantly...

The very earth heave[s] and sh[akes] ... and a terrible thunder ren[ds] the skies.

(p.2).

The deployment of Judaeo-Christian imagery in postnuclear texts is beyond the scope of this paper, but it is significant to observe how frequently language from these myths is used when discussing the nuclear issue, both in literature and in popular discourse. In addition to the frequent use of the word 'Armageddon' and the first plutonium bomb being code-named 'Trinity'. Iife before and after Hiroshima has often been likened to the difference between B.C. and A.D. (Ruthven 1993, pp.1 and 4). One of the results of this use of religious and quasi-religious language is that it encourages the impression that nuclear power is something over which the individual can have little control and which might even be inevitable. Far from the concept of 'think globally, act locally', or the 'Uranium? No thanks' badges which were popular during the 1970s, the use of words such as 'Armageddon' and 'Trinity' suggest that a nuclear disaster is an archetypal (and by implication necessary) experience about which an individual cannotand perhaps should not-do anything.

This latter point is one which Carmody takes care to address. lgnoring the fact that the land is beginning to recover after the Great White, the religious order formed by the Council believes that the 'Holocaust was a punishment from God, whom they call Lud' (1987, pp.2 and 3). "The fact that the religious order is presented as evil suggests that Carmody is discouraging her readers from taking the view that a nuclear disaster is divine punishment. For example, the young Herder who travels with Elspeth and her party at the very beginning of 
Obernewtyn 'represent[s] the true danger which I[ies] ahead' (p.7). Similarly, despite claiming to speak in the voice of Lud (God), the Herders have often been in the habit of 'doing what they wish' which can also involve denying people justice (1995, pp.2 and 4).

Far from seeing the nuclear catastrophe (1999, p. 158) as divine punishment or a necessary archetypal experience, Carmody encourages her readers to see it as the result of a particular way of human thinking which can be contested by the reader, and which is susceptible to change. As John Stephens notes, because most post-disaster fiction (which of course embraces a wider field than just the postnuclear) is set in the future, when the texts muse on the past that past is often actuaily the reader's present (1992b, p.126). Since the mistakes which caused the nuclear holocaust have been in the past in terms of the text, the logical conclusion is that the reader has the power to avoid those mistakes happening and-by implicationto prevent the holocaust from occurring. Instead of the simplistic view that the 'Great White' was a punishment from God, Carmody, focalising through Elspeth, suggests several other reasons for the disaster. After looking at Kasanda's carvings of the Beforetime, Elspeth comes to the conclusion that the Holocaust was 'the inevitable conclusion to the arrogant, greedy, self-centred age of the Beforetimers' (1999, p.36). In this instance readers are positioned to contest the arrogance. greed and selfcentredness' of the Beforetimers, so that the text proposes that people must change their ways now, before it is too late. However, if it does become 'too late', a nuclear disaster will be the natural consequence of humanity's own actions, not the retribution of a supernatural being.

Not only is the language of myth utilised in the Obernewtyn chronicles to promote ideologies, but the characters' style of speech encourages a particular ideological stance. For example, instead of 'words' to communicate, the animals use 'thoughtsymbols', and their style of speech is fluid, accommodating many ambiguities without trying to resolve them: ' $[B]$ easts know not all of a kind are born alike/exact. None can know what darkness/madness drives the funaga' (1999, p.10). The reader's sympathetic alignment with Elspeth is encouraged by her 'talking' in a similar fashion (1999. p.11). This suggests that she is in harmony with other living things, which is one of the central ideological tenets of the series (see, for example, 1993, p. 289). The animals in Carmody's texts are therefore aware - as Carmody encourages her readers to be-that language can often construct a 'reality' which is not what it seems. The instability of meaning in language is highlighted in two episodes in particular: in her attempt to understand the message from the mysterious Kasanda $(1999, p .414)$ Elspeth comes to learn that the 'key' is in fact the mysterious Dragon (1999, p.744). On a similar note, eariy in The Keeping Place Maruman the cat chides Elspeth and the human race in general for their desire to put names on everything, "even things which cannot be named' (p.4).

The world of Obernewtyn is one which is in theory a future version of our own (for example, Elspeth and her contemporaries are descended from the people who lived before the holocaust; yet it is at the same time different. This is reflected in the language of the text. For example, as mentioned earlier, 'Talented' in Carmody's world means being telepathic (1999, p.428), like Elspeth; or, in the view of those who oppose her, she and those like her are seen as Misfits $(1987$, p.3). Carmody has, however, removed the sting from the word 'Misfit' by linking it with the more favourable word 'Talented'. On the other hand, to be 'normal' is not necessarily a good thing in Carmody's world, since the evil Council issues 'Normalcy Certificate[s]' (1993, p.2). 'Normal' is thereby constructed as an undesirable trait for it links people with the oppressive Council. And in a wider sense within the group of Misfits it is better not to be normal; the heroine Elspeth, for example is outstanding even within the Misfits (1995, p. ix). Rushton, also, is ashamed of his apparent 'Normalcy' (ie: his seeming lack of telepathy) and it is not until the end of the third novel in the series that lip service is paid to the idea that not to be telepathic is not necessarily a bad thing (1995, p. 516). Lip service it is indeed, however, for Rushton is mainly absent from the fourth novel and has to be rescued (albeit almost by accident) by the other Misfits (1999, p.648)

Carmody utilises words and labels from our own time, but these words often have a different meaning from their commonly-accepted meanings. The word 'government', 
for instance, might seem to possess a relatively stable meaning, but the 'Govamen' in Carmody's texts is described as 'a mysterious organization ... with sinister connections to weapon machine makers' (1995, p.26). Similariy, names such as Tipoda, Uropa, Chinon Empire. Raq, Turka and Mericanda (Carmody, 1999, pp. 107 and 112) suggest the Antipodes (Australia?), Europe, China, Iraq, Turkey and America. There is a sense that early twenty first century dwellers may see these powers as significant in either world or personal terms, but that that power will certainly not last for ever. Again, the reader is made aware of the unstable relationship between signifier, signified and referent.

The ways in which language can be constructed both as a means of encoding power and as a way of encoding slippages of ideology and significance are explored in Carmody's texts. For example, Dardelan is described as 'us[ing] words as a fisherman trawls his net or casts his line', but his words have power because they come 'from his heart and deepest beliefs'. In this manner he is able to persuade the citizens of Sutrium that the laws he is proposing are the best ones possible (1999, p.656). Being literal in the way one uses words can also even allow the enemy to get what $s /$ he wants, albeit in the short term. It is by being totally honest in his language that Malik manages to outwit the Misfits (including the empaths). for he promises not to hurt the soldierguards while all the time he is actually planning to destroy the Misfits (1999, p.566).

This notion of language creating disinformation rather than communication (see Ruthven 1993,p.56) is also evident in $Z$ for Zachariah. The reference to the alphabet in its very title highlights an interest in language and the fact that the initials of the chief protagonist-Ann Burden-are at the opposite end of the alphabet to Zachariah suggests momentarily that the world is being defined in terms of a linear, familiar and potentially simplistic understanding of language. It is as if between the two of them Ann Burden and 'Zachariah' contain the whole world, both in a linguistic and a 'real world' sense. However, O'Brien shows that this is a naive view to take, since the book from which this image originates is a book 'for small children' (p.58). Neither language nor the world which people seek to make it represent can be quite so easily contained. Indeed, the 'reality' which seems to be constructed by the actual language $\mathrm{O}^{\prime} \mathrm{Bricn}$ uses is very different from what many a reader would sense is going on underneath. The fact that the novel is told in diary form (see, for example pp. 7 and 8 ) actually invites the reader to focus on language: the reader is aware far more than in other means of storytelling that what is recorded is very selective, so that the reader may be able to reach conclusions which are unavailable to the author. The result of this can be a dislocation between what the diarist writes and what the reader is able to infer is going on.

A reader, for example, is likely to think it strange that Ann always refers to the scientist as 'Mr Loomis', despite the fact that she entertains fantasies of marrying him, before he almost rapes her and then shoots her (pp.62, 133. 166). Although Ann is of an age and the novel published at a time when, from my own memories at least, teenagers were expected to call adults outside their own family by their surname, this insistence on a formal title for someone who has had such a profound and unsettling effect on Ann's life is a constant reminder of how language can act as a barrier to reality. The formal, polite, respectful veneer created by Ann's words is at serious odds with the terror of what is really going on in her situation: a powerhungry, guilt-stricken, insecure man is attempting to make Ann his slave in every sense, not the least being his attempt to dominate her sexually. Ann's politeness underscores her virtue but also the limitations of the world in which she has been brought up, since she will not be rude even to a man who threatens her life. This suggests that her independence and the courage with which she deals with her situation is represented as all the more remarkable. The politeness also sets her up in binary opposition to Mr Loomis, who 'curs[es] Edward in terribie language' whose 'profanity' Ann refuses to record (p.89). Indeed, one of the most powerful aspects of the rape scene is that it is so completely void of language: the terror, although described in words, is void of words. Ann, for example, "knows what [Mr Loomis] is planning to do as clearly as if he [has] told [her]' and any conversation between them would in all likelihood have lessened the impact of the attack for the reader (p.133). 
The gap between what is said and what the reader is invited to construct is particularly evident in Why Weeps the Brogan? Saxon and Gilbert speak in a style which is somewhat awkward, suggesting phrases from another generation and location from that in which they find themselves. 'We must find a tie for your hair', 'Proceed'. and 'You may do it', (pp.10,-21 and 39) all suggest the language of adults. In using this style of discourse. Saxor and Gilbert answer their own question: 'Perhaps ... we have been here for ever' (1991, p.9). They must, after all, have heard the language from somewhere, yet they are not aware that they have found their own answer. It is this gap between what the protagonists know and what the reader is able to work out that form much of the tension in the novel: will Saxon and Gilbert's construction of reality come closer to consensus reality, will it diverge altogether, or will it do something quite different? This gap between the children's knowledge and the implied reader's is demonstrated in the scene (which happens before the time of the novel) during which Saxon and Gilbert ask "What is bomb and warhead and missile?" But they [have] no answers" (p.15). The irony of course is that it is because of bomb and warhead and missile that the action of the novel takes place at all.

The dark museum is also a world in which labels and words have little meaning: as Gilbert himself says, 'Even the meaning has no meaning' (p. 56). EGYPTOLOGY (p.29) for example, is distinguishable from PRIVATE STAFF ONLY merely by virtue of being another room. An experienced reader, however. knows that EGYPTOLOGY is a display area, whereas PRIVATE STAFF ONLY has a different function.

This unstable relationship between signifier and signified is emphasised in Scott's use of the adjective 'correct', to which he assigns at least nine different definitions:

1. Tasting pleasant (p.10)

2. Well prepared (p.11)

3. Appropriate (p.15)

4. Precisely enumerated (of articles in a list) (p.30)

5. A good way to solve a problem (p.36)

6. Inspired (p.45)

7. Calm, under control (p.50)

8. Healthy, despite appearances to the contrary (p.90)

\section{Predictable, understood (p.94)}

Many of these uses of 'correct' are unusual in the way most people normally think of the word. In this way, Scott has produced a dislocation in the novel which challenges the reader's expectations, and thus heightens the tension produced within the text. In addition to the unorthodex use of language, this tension comes about in part through Saxon and Gilbert's attempts to discover their last name and the reason for the mysterious Brogan's sadness (see, for example, Scott 1991, pp.38 and 69). These questions may seem trivial out of context, but are vital within the novel's narrative shape. The use of a conventional signifier for unconventional purposes invites the reader to question the capacity of language to represent anything at all. Scott does not let his readers take anything for granted, even the commonly agreed meaning of a word (meaning is, of course, itself unstable, but there is a generally accepted core of meaning in our society which Scott's use of the word 'correct' challenges). Saxon and Brogan's use of language invites the reader to consider just how arbitrary our means of making sense of our world actually is. And it is a neat irony that Scott has chosen the signifier 'correct' as his tool for doing this. 'Correct', after all, is often considered of in terms of binary oppositions: something is either correct or it isn't. Scott is not only challenging that view, but also reminding his readers of the instability of meaning and, by implication, of consensus reality.

'Correct' is also an important word for Jim and Hilda in Raymond Briggs's When the Wind Blows. However, the way the word is used in Briggs's text is very different from the contortions through which this particular set of letters pass in Why Weeps the Brogan? For Jim and Hilda, being correct means doing what the 'government' says. Jim, for example, insists that they 'must do the correct 'thing' and stay in their 'Inner Core or Refuge' - which the reader can see is clearly useless (Briggs 1982, p.24). In addition, Jim suggests that the long term effects on those who did survive the bombing of Hiroshima were in part because 'they neglected to do the correct thing' (Briggs 1982, p. 31). There is an implication that if the citizens of Hiroshima had done what the authorities had told them to. then the effects of the bomb would not have been so 
devastating. The reader, however, is positioned to know that this is not true. The government's use of propaganda and euphemism may lull Jim and Filda into a false sense of security, but for those who can see through this attempt to dupe it only emphasises the tragedy of the situation. However, whilst readers in their helplessness may identify with Jim and Hilda, many people may be reluctant to align themselves with Jim and Hilda's naïveté. Briggs, however, gives his audience another character with whom to identify, albeit briefly: Jim and Hilda's son Ron. He is, in a sense, the voice of sanity in the text, "killing himself laughing' when his father asks him about angles just before the nuclear blast. Ron knows what readers are being invited to see but which the central characters do not: that if the bomb is dropped we will 'cop it' indeed (p.3).

The tragedy of Jim's naiveté, as well as his attempts to cling to the emptiness of words which have no intrinsic meaning is highlighted by his inability to explain to Hilda the meaning of 'Inter-Racial Harmony in a Multi-Ethnic Society'. When asked 'What does it mean?' he responds, 'I don't know.... just liked the words' (Briggs 1982, p.24). The tragedy of this is at least twofold: that genuine 'inter-racial harmony' might actually have avoided warfare in the first place, and secondly that if it came to the point when nuclear weapons were used then it would not matter whether people were able to decode conventional sign-thing relationships or not. Much of the humour and pathos in the book comes from Jim and (especially) Hilda's interpretation of words in a particular context. In addition to the 'Fall Out/fall' in the example mentioned earlier, Hilda interprets the County Council's Directive to 'stimulate group activities' as a reference to sex; an allusion she maintains when Jim starts talking about 'World Affairs' (p.24). Jim also, of course, does not understand the new jargon, being confused about whether they are bang in the middle or in the middle of the bang, and wondering also whether the technical name for where the bomb falls is the Epi-centre or the Hypo-centre (p.22). The tragedy, of course, is that it does not matter, and the reader is thus again implicitly encouraged to exercise agency conceming nuclear proliferation while the meaning assigned to words does matter.
This fascination with language, names and meaning in post-nuclear fiction also invites readers of the genre to examine how individuals perceive their own realities, and how consensus reality can both be questioned and taken for granted. It is an interesting irony in post-nuclear fiction that words can be presented at times as lacking any intrinsic, stable meaning, and other times as having the power to construct a particular view of the worid or to promote a particular ideology. Sometimes this dichotomy is made cbvious and at other times not, but the reader who realises this duality will be in a stronger position both to engage with the text and to examine the ideological positions (both overt and covert) which are being presented.

\section{NOTES}

1. AMIRV is a 'multiple independently-targeted re-entry vehicle', a MARV is a 'manoeuvrable re-entry vehicle' and FOBS are 'fractional orbital bombardment systems' (Ruthven 1993, pp.57, 56).

2. It is, of course, a subset of the more general 'postdisaster fiction'. For discussions of post disaster fiction see Le Guin 1992 and (in particular) Stephens 1992b.

3. See James T. Henke's article 'Growing up as epic adventure: the biblical collage in $Z$ for Zachariah'.

4. This name has interesting connotations, since it was Ned Ludd who reputedly led the riots smashing machines during the Industrial Revolution (Cootes, 1968, p.119). One of the tenets of the Council in Carmody's texts is that the machines belonging to the old world should be destroyed (1987, p.2).

\section{REFERENCES}

Bible, Revised Standard Version.

Briggs, Raymond (1982) When the Wind Blows. London. Hamish Hamilton.

Carmody, Isobelle (1987) Obernewtyn. Ringwood, Penguin.

Carmody, Isobelle [1990] (1993) The Farseekers. Ringwood, Penguin. 
Carmody, Isobelte (1995) Ashling. Ringwood, Viking.

Carmody, Isobelle (1999) The Keeping Place. Ringwood, Penguin.

Cootes, R.J. (1968) Britain Since 1700. London, Longman.

Dobson, Jill (1988) The Inheritors. St Lucia, University of Queensland Press.

Henke, James $T$. (1982) 'Growing up as epic adventure: the biblical collage in $Z$ for Zachariah', Children's Literature in Education 13, 2, 87-94.

Hoban, Russell (1980) Riddley Walker. London, Jonathan Cape.

Hollindale, Peter (1988) 'Ideology and the children's book', Signal 55, January, 3-22

Keene, Suzanne (1991) ' $Z$ for Zachariah: A modern appraisal', Reading Time 35, 1, 6-7.

Lawrence, Louise [1985] (1986) Children of the Dust. London, HarperCollins.

Le Guin, Ursula (1992) Dancing at the Edge of the World: Thoughts on Words, Women. Places. London, Paladin.

O'Brien, Robert C. [1975] (1976) Z for Zachariah. London, Fontana Lions.

Ruthven, Ken (1993) Nuclear Criticism. Melbourne, Melbourne University Press.

Scott, Hugh [1989] (1991) Why Weeps The Brogan? London, Walker Books.

Stephens. John (1992a) Language and Ideology in Children's Fiction. London and New York, Longman.

Stephens, John (1992b) 'Post-disaster fiction: The problematics of a genre', Papers 3, 3, 126-130.

Swindells, Robert [1984] (1985) Brother in the Land, Penguin, London.

\section{BIOGRAPHICAL NOTE}

Elizabeth Braithwaite teaches at Box Hill Institute. Her interests include reading, music and cycling, and she is married with a daughter, Caroline.

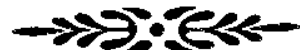

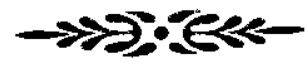

Papers 10: 22000 